\title{
Outras determinações do "crítico"
}

\author{
Jorge Alberto Rocha
}

\section{SciELO Books / SciELO Livros / SciELO Libros}

ROCHA, JAC. Outras determinações do "crítico". In: Michel Foucault: crítico-esteta-cínico mitigado [online]. Campina Grande: EDUEPB. Substractum collection, 2014, pp. 153-210. ISBN 978-85-7879-

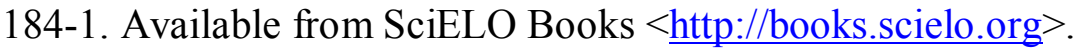

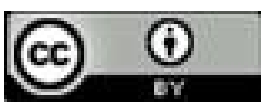

All the contents of this work, except where otherwise noted, is licensed under a Creative Commons Attribution $\underline{4.0 \text { International license. }}$

Todo o conteúdo deste trabalho, exceto quando houver ressalva, é publicado sob a licença Creative Commons Atribição 4.0.

Todo el contenido de esta obra, excepto donde se indique lo contrario, está bajo licencia de la licencia $\underline{\text { Creative }}$ Commons Reconocimento 4.0. 


\section{Outras determinações do "crítico"}

Resumindo a questão da crítica, no sentido de como a entende Michel Foucault, esta passagem aparece de forma privilegiada: "Uma crítica não consiste em dizer que as coisas não são bem como elas são. Ela consiste em ver sobre quais tipos de evidências, de familiaridades, de modos de pensamento adquiridos e não refletidos repousam as práticas que se aceita" (FOUCAULT, "Est-il donc important de penser?", DE, IV, 1994, p. 180). Portanto, há de se entender que as "evidências", nas quais transitamos a partir das nossas crenças e atitudes mais comuns e rotineiras (este é um bom sentido para o "familiar" foucaultiano), devam sempre ser colocadas em xeque, de antemão.

Mas o referido "resumo" do conceito de crítica em Foucault peca pelo seu caráter sintético. O que irá marcar o seu traço personalístico como um “crítico" será o conjunto arquitetônico do seu pensamento, os elementos que transitarão, como diria Deleuze, por sua "máquina abstrata". É mais uma vez no texto "Crítica y Aufklärung" (FOUCAULT, 1995, p. 5) que elementos importantes são lançados por Michel Foucault, cuja problemática do poder estará posto a todo o instante, juntamente com o do sujeito e da verdade. 


\section{Sujeito-verdade-poder}

Analisando as práticas de governamento ocorridas nos terrenos da religião, do Direito e da ciência, bem como o seu reverso: as atitudes críticas que se lhes contrapuseram - já se viu que Foucault diz ter sido o "núcleo da crítica" a relação poder-sujeito-verdade (FOUCAULT, 1995, p. 5). Ou seja, nas suas palavras, "a crítica é o movimento por meio do qual o sujeito se atribui o direito de interrogar a verdade sobre os seus efeitos de poder, e ao poder sobre seus discursos de verdade" (FOUCAULT, 1995, p. 5). É preciso entender como esses três elementos daquela tríade em Foucault são construídos, a fim de dar conta do seu entendimento particular da questão crítica.

Em uma entrevista tardia, que já faz parte do seu terceiro grande momento (a genealogia da ética, a ser abordado mais a frente), Foucault menciona essa preocupação do Ocidente de buscar uma "obrigação de verdade", de dizê-la, de alcançá-la; ao mesmo tempo, de seu entrelaçamento com o poder. Grosso modo, facultando a existência de coisas e excluindo outras (FOUCAULT, "L'ethique du soici de soi comme pratique de la liberté", DE, IV, 1994, p. 723). Nessa mesma entrevista ele diz que os problemas econômicos podem ser resolvidos; "restam", porém, os problemas decorrentes dos "excessos de poder", como a guerra da Argélia, as intervenções russas etc... (FOUCAULT, "Pouvoir et savoir", DE, III, 1994, p. 401). Em outros momentos ele se reporta a maio de 1968 na França (FOUCAULT, “Non au sexe roi”, DE, III, p. 264) e, de resto, 
encontra-se várias situações cuja biografia foucaultiana dão exemplos curiosos e dramáticos. ${ }^{46}$

Tudo isso, seja no plano teórico, seja no plano biográfico, afunilava-se rumo à imbricação sujeito-verdade. Para Michel Foucault a história do conhecimento no Ocidente obedeceu durante muito tempo a duas exigências: à manutenção de uma relação com a soberania do sujeito, presente em termos como 'tradição', 'mentalidade', 'modos'; e uma segunda, não buscando propriamente "salvar o sujeito, mas a verdade", a saber, esta não se constituindo na história, mas "se revelando" nesta (FOUCAULT, "De la nature humaine: justice contre pouvoir", DE, I, 2001, p. 1348).

Para Foucault o sujeito foi "priorizado" pela filosofia, sobretudo, com autores como Descartes e Kant. E ainda que não se queira concordar com ele acerca disso, há uma plausibilidade em tal ideia. Descartes, em obras como o Discurso do método (1979), traz o pensamento e a existência (do sujeito)

46 Há importantes referências biográficas de Foucault sobre o que se está falando, sobretudo em Eribon (1990). Este autor escreve que Michel Foucault, aos 14 anos, então estudante do colégio São Estanislau, vivia numa França "há algumas semanas ocupada pelos alemães", e os horrores da guerra já batiam a porta (ERIBON, 1990, p. 20). Ele ainda acrescenta a questão do seu homossexualismo em 1950, onde fazia questão de manter velado numa França ademais preconceituosa, "'época da vergonha e da clandestinidade', no relato de Dominique Fernandez" (ERIBON, 1990, p. 43). A conclusão de Eribon é que Foucault teria inventado "uma aventura intelectual nos combates da vida individual e social, não para neles se ficar preso, mas para os meditar, os ultrapassar, os problematizar" (ERIBON, 1990, p. 45)... E combate até mesmo na expressão da palavra: afinal, como relatou um professor do Collége de France em 1971 a Dumézil, não seria Foucault visto ao lado de Sartre e dos esquerdistas em inúmeros protestos? Não encabeçaria cortejos de imigrantes e instalar-se-ia nos portões das prisões? 
como os portos seguros da dúvida que encabeça o "cogito" e todo o clima de ceticismo da sua época. Tanto a dúvida, quanto o pensamento e a existência são ancorados, pois, em um sujeito que duvida, em um sujeito que pensa e que existe. Ao final, a certeza desse sujeito é que é assegurada, e aí estarão dadas as possibilidades do conhecer, através de um processo interno e subjetivo, onde a razão, apartada do espaço fenomênico, deverá por si mesma julgar o que, por exemplo, um fenômeno sugere: os exemplos da cera, do autômato e do sonho, em Meditações (DESCARTES, 1979a) espelham isso.

Kant, por seu turno, modela toda a compreensão da realidade, a partir do seu idealismo, como fundação eminentemente humana: é sob a nossa lente espacial e temporal, unida às categorias do entendimento, que o objeto é posto naquilo que ele é, a saber, um fenômeno, o que aparece. Em função disso é que o noumeno ou essência termina sendo o inapreensível ou incognoscível, a menos que se queira ir além das possibilidades cognoscentes humanas, deixando aí de lado o caráter crítico da filosofia; quer dizer, a menos que não se observe os limites da nossa razão (KANT, 1985).

Para Michel Foucault a tradição filosófica conservou, pelo menos após Descartes, chegando a Sartre, esse primado do sujeito. Falando sobre a sua geração, diz ele que ela ou era baseada na Fenomenologia, com o primado do sujeito constituinte, ou no marxismo, com seu relevo dado ao econômico e ao "jogo das superestruturas e das infra-estruturas" (FOUCAULT, "Entretien avec Michel Foucault", DE, III, 1994, p. 147). Vertentes não seguidas por ele, a saída achada consistiu em historicizar o sujeito dos fenomenólogos e dar àquele "uma consciência que se transforma através da história". O 
sujeito constituinte ou tomado em si mesmo desaparece, pois, uma vez reconduzido à sua constituição forjada na trama histórica. E a pesquisa genealógica fica livre, então, para buscar os saberes, discursos e domínios do objeto "sem ter que se referir a um sujeito" (FOUCAULT, “Entretien avec Michel Foucault", DE, III, 1994, p. 147).

Quanto ao marxismo, para além de inúmeras querelas, Foucault vai se opor, por exemplo, à ideia de ideologia. Demarcando a noção de que existe uma realidade objetiva e concreta, de um lado, e um espaço teórico-idealizado, do outro, Foucault pensa que não há como escapar da ideia aí presente de uma verdade escondida, de um determinante econômico e de um sujeito que, preso nessa malha ilusória, termina perdendo a si mesmo em um processo alienante (FOUCAULT, “Entretien avec Michel Foucault”, DE, III, 1994, p. 148).

Freud questionou esse crédito maior dado ao sujeito, mostrando que o homem é apreendido a partir das suas manifestações inconscientes, e não das posições claras e distintas que um sujeito possa fazer conscientemente. Para Michel Foucault, coube à psicanálise reavaliar "mais profundamente a prioridade um pouco sagrada conferida ao sujeito", devendo este ser colocado como alguém que é "fundado e refundado pela história" (FOUCAULT, "Sexualité et politique", DE, I, 2001, p. 1408). Mas foi Lacan que destronou o sujeito de maneira contundente, liberando-nos da oposição sujeito como radicalmente livre ou sujeito como determinado por condições sociais (FOUCAULT, “Lacan, le 'libérateur' de la psychanalyse”, DE, IV, 1994, p. 205). 
Voltando os olhos para a tradição filosófica, melhor seria seguir os passos de autores como Nietzsche. Segundo Roberto Machado (2000, p. 11), foi a partir dessa vertente filosófica que Foucault pôde se conectar com certos representantes da literatura - principalmente Hölderlin, Sade, Roussel, Flaubert, Mallarmé, Artaud, Bataille, Blanchot e Klossowski - além de outros autores como Barthes e Althusser, Wagner e Shopenhauer, todos esses questionando a "forma originária e autosuficiente" do sujeito, vinda desde a época cartesiana, ou questionando, dá no mesmo, a tendência antropológica da filosofia. Por fim, o Estruturalismo aparece fazendo coro com essa crítica: como visto, a estrutura não coloca o sujeito como algo de fundamental, mas como alguém que, antes de tudo, está preso em certas "estruturas", possuindo nestas o seu lugar e a possibilidade do seu "movimento", como num tabuleiro de xadrez (FOUCAULT, "La scène dela philosophie", DE, III, 1994, p. 593).

Enfim, pensando primeiramente na relação sujeito-verdade, interessante é observar o que diz o verbete "Foucault" (FOUCAULT, DE, IV, 1994, p. 631): falando sobre si mesmo, a possibilidade de ele estar inscrito na tradição filosófica é pela continuação daquela da tradição crítica, inaugurada por Kant. Mas o que é fazer uma história crítica do pensamento? Não significa nem fazer uma história das ideias (e dos possíveis erros interpostos nessa tradição) nem uma "decifração dos não reconhecimentos aos quais ela estaria ligada". Ou seja, "Não se trata de definir as condições formais de uma relação ao objeto"; antes, ao invés de tomar o pensamento como um sujeito endereçado para um objeto, trata-se de "determinar o que deve ser o sujeito, a qual condição ele está submetido, qual status deve ter, qual posição deve ocupar na realidade 
ou no imaginário, para tornar sujeito legítimo de tal ou tal tipo de conhecimento; em resumo, trata-se de determinar o seu modo de 'subjetivação"' (FOUCAULT, "Foucault", DE, IV, 1994, p. 631).

Por outro lado, deve-se ainda determinar o seu modo de objetivação, no sentido de investigar em "quais condições alguma coisa pode tornar um objeto para um conhecimento possível" (FOUCAULT, “Foucault", DE, IV, 1994, p. 631, grifo nosso). Em outras palavras, como uma determinada realidade pode ser "objetivada" ou como ela pode "ser problematizada como objeto a conhecer" (FOUCAULT, "Foucault", DE, IV, 1994, p. 632), eis a questão colocada por Michel Foucault. E mais: qual é mesmo a relação que se estabelece entre esse algo objetivado e os processos de subjetivação que são instaurados aí, a saber, objetivação e subjetivação cujo desenvolvimento de ambos se dá de forma "mútua" ou de ligação "recíproca"?

Sujeito-verdade: pensa-se que as referências acima tocaram em elementos fundamentais acerca dessa relação. Mas e acerca da tríade sujeito-verdade-poder? Em primeiro lugar, Foucault não partilha da imagem límpida e transparente atribuída ao conhecimento e, consequentemente, à noção mais tradicional de verdade como adequação da coisa com o intelecto. Sua posição busca resgatar o caminho traçado por autores como Nietzsche. Em A gaia ciência (2001), Foucault interpreta a compreensão de Nietzsche com o conhecimento como uma invenção, atrelada a um "jogo de instintos, impulsos, desejos, medo, vontade de apropriação"; que é produzido não como efeito de harmonia, mas de rancor ou ódio (haine); que há sempre um interesse por detrás (relativamente àqueles instintos); que é menos um conhecimento da verdade do que 
a produção de uma verdade por meio de uma "falsificação primeira e sempre reconduzida que põe a distinção do verdadeiro e do falso" (FOUCAULT, "La volonté de savoir", DE, I, 2001, p. 1111).

Assim, diz ele acerca do conceito de verdade: por esta eu "entendo um conjunto de procedimentos regulados para a produção, a lei, a repartição, a circulação e o funcionamento dos enunciados" (FOUCAULT, "La fonction politique de l'intellectuel”, DE, III, 1994, p. 113). Há, pois, uma ligação circular entre os "sistemas de poder que a produzem e a sustentam e aos efeitos de poder que ela induz e que a reconduzem. 'Regime' da verdade"; tal regime não é "simplesmente ideológico ou superestrutural”. Diz então Foucault:

[...] o problema político essencial para o intelectual não é criticar os conteúdos ideológicos que seriam ligados à ciência, ou de fazer de forma que sua prática científica seja acompanhada de uma ideologia justa. Mas de saber se é possível constituir uma nova política da verdade. $\mathrm{O}$ problema não é de mudar a consciência das pessoas ou do que elas têm na cabeça; mas o regime político, econômico, institucional de produção da verdade; [a tarefa, pois, é] desprender o poder da verdade das formas de hegemonia (sociais, econômicas, culturais) no interior dos quais por um instante ela funciona (FOUCAULT, "La fonction politique de l'intellectuel", DE, III, 1994, p. 114). 
Outra forma de se pensar nos discursos e na sua relação com a verdade e o poder é recusar ter uma posição dualista: discursos dominantes, de um lado, geralmente representados por classes dominantes, com as suas formas de repressão, exclusão etc., e discursos dominados, de outro - justamente, os que sofrem com as barreiras impostas pelos discursos hegemônicos. Os discursos estão instalados previamente em um "campo estratégico", o que significa dizer que ambos os supostos lados não param de se afrontar, onde "os elementos, as táticas, as armas não cessam de passar de um campo ao outro" (FOUCAULT, "Le discours ne doit pás être pris comme...", DE, III, 1994, p. 123).

Cada sociedade tem seu regime de verdade, sua política geral de verdade: quer dizer, os tipos de discurso que ele acothe e faz funcionar como verdadeiro; os mecanismos e as instâncias que permitem dintinguir os enunciados verdadeiro ou falso, a maneira pela qual se sanciona uns e outros; as técnicas e os procedimentos que são valorizados para a obtenção da verdade; o estatuto daqueles que tem a charge de dizer o que funciona como verdade (FOUCAULT, "Entretien avec Michel Foucault, DE, III, 1994, p. 158).

Enfim, por verdade ele entende "não uma espécie de norma geral, uma série de proposições. Eu entendo por verdade o conjunto de procedimentos que permitem a cada instante e a cada um de pronunciar enunciados que serão considerados como verdadeiros" (FOUCAULT, "Pouvoir et savoir", DE, III, 1994, p. 407). Daí o binômio verdade-poder, ao invés de 
ciência-ideologia; daí o horizonte a ser perquirido: "os problemas políticos dos intelectuais" (FOUCAULT, "Entretien avec Michel Foucault", DE, III, 1994, p. 159). Acrescentando-se aqui a necessidade de uma pesquisa regional: como o poder que se exerce sobre a loucura produziu o discurso verdadeiro da psiquiatria? Mesma coisa para a sexualidade (FOUCAULT, “Non au sexe roi", DE, III,1994, p. 257).

Dessa forma, se a história do Ocidente não deveria ter deixado de lado o tema da verdade, devia ser no sentido de como ela foi produzida em cada época e situação e de como produziu os seus efeitos. Esta lacuna, porém, foi a que mais perdurou: "A história da 'verdade' - do poder próprio aos discursos aceitos como verdadeiros - está inteiramente por fazer" (FOUCAULT, “Non au sexe roi”, DE, III, 1994, p. 258). Mais adiante, nessa mesma entrevista ele diz ter sido "sempre meu problema: efeitos de poder e produção de verdade" (FOUCAULT, “Non au sexe roi”, DE, III, 1994, p. 263).

Sujeito-verdade-poder encontra ainda outra ancoragem fundamental: a que liga essa tríade à questão do "teatro". Mais precisamente, diz Foucault, a questão "filosofia, verdade e teatro" precisou aguardar Nietzsche, mais uma vez. Platão e Descartes colocaram questões como o que é verdade e realidade, o que é ilusão e mentira. No caso do filósofo grego, ainda não abordado aqui, o famoso "mito da caverna" traz a ideia de que há uma "luz" esperando pelos homens para além da sua caverna de "sombras", ou ignorância. E se essa saída é por si mesma penosa: ver o sol do conhecimento após tanto contemplar formas sombreadas dói e ofusca por completo a visão, a descoberta paulatina da verdade trará libertação e felicidade (PLATÃO, 2000, p. 225). 
O "teatro" Nietzsche-foucaultiano é diferente. Suas cenas não querem selar razões, conhecimentos ou verdades, ao preço de coisas que seriam irracionais, mentirosas ou falsas: "Ora, o teatro é alguma coisa que ignora absolutamente essas distinções. Não tem sentido se perguntar se o teatro é verdadeiro, se ele é real, ou se ele é ilusório, ou se ele é mentira; o único fato de pôr a questão faz desaparecer o teatro". Sem buscar instalar-se na questão de saber se a medicina ou a psicanálise são verdadeiras ou falsas, o que importava para Foucault era a "encenação" da doença, da loucura, do crime, "quer dizer, como as pessoas as percebiam, qual o valor dado, qual papel representava" (FOUCAULT, "La scène de la philosophie", DE, III, 1994, p. 571).

Nesse "teatro da verdade" o poder ressoa a todo o instante, não mais no âmbito de alguma espécie de oposição: a verdade afronta o poder, intimida-o ou o denuncia. Ao contrário, há mesmo uma imbricação entre os termos, uma necessidade complementar entre ambos, e a política é um palco privilegiado disso:

Nada é mais inconsistente do que um regime político que é indiferente à verdade; mas nada é mais perigoso do que um sistema político que pretende prescrever a verdade. A função do 'dizer verdade" não tem que tomar a forma da lei [...]. A tarefa do dizer verdade é um trabalho infinito: a respeitar em sua complexidade é uma obrigação na qual nenhum poder pode fazer a economia. Salvo ao impor o silêncio da servidão" (FOUCAULT, "Le souci de la vérité", DE, IV, 1994, p. 678). 
Ora, a verdade é alguma coisa que, pelo menos numa apreciação tradicional e com todo o peso que ela sempre solicitou, quer universalizar-se. Desinteressando-se por isso, o importante é buscar o "acontecimento", que foge ao caráter de eternidade da verdade. Compactuar com a imagem tradicional mais acima significaria não conceder a Michel Foucault o personagem conceitual de filósofo, e ele assume isso em "La scène de la philosophie" (FOUCAULT, "La scène de la philosophie", DE, III, 1994, p. 573). Mas sem problemas, pois o interessante para Michel Foucault é perceber os processos que atravessam as pessoas, movimentos e forças não conhecidas, e só aí ele se aproximaria do "papel do filósofo". Como já visto, ser um diagnosticador dessas forças, diagnosticar a atualidade (FOUCAULT, "La scène de la philosophie", DE, III, 1994, p. 573).

Se, pois, há forças passam pelos sujeitos, melhor pensar não propriamente na verdade que algum sujeito pudesse adquirir, mas em processos de subjetivação. "Eu chamaria subjetivação o processo pelo qual se obtem a constituição de um sujeito, mais exatamente de uma subjetividade, que só é evidentemente uma das possibilidades dadas de organização de uma consciência de si" (FOUCAULT, "Le retour de la morale", DE, IV, 1994, p. 706). O sujeito em Sade desaparece na medida em que este autor dá privilégio à "força infinita do desejo", ao invés de realçar o poder consciente do sujeito. Se há uma necessidade de abolir tal privilégio é na medida em que o sujeito se torna não mais do que "um elemento no interior de uma combinação", e esse questionamento da pessoa individual é sinal de que hoje vive-se em "uma profunda crise da sociedade" (FOUCAULT, "Les problèmes de la culture. Um débat Foucault-Preti”, DE, I, 2001, p. 1244-1245). 
Michel Foucault não chegou a fazer uma teoria específica sobre o poder. A começar pela ideia de que isto - "o" poder - não existe, senão que ele é sempre relacional, ele se constitui a cada instante, ele, sobretudo, "funciona". É preciso "não tomar o poder como um fenômeno de dominação massiva e homogênea", uma vez que ele circula e funciona, ou seja, "jamais é localizado aqui ou ali", o poder "transita pelo indivíduo que ele constituiu" (FOUCAULT, Cours du 14 janvier 1976, DE, III, 1994, p. 180).

Uma tarefa fundamental a ser perquirida é, portanto, buscar os "mecanismos infinitesimais" nas relações de poder. Assim, é "fácil" - e por isso reprovável - dizer que os loucos foram internados baseados em inúmeras justificativas plausíveis, ao invés de buscar uma causa atrelada às pretensões de uma burguesia que, a partir dos séculos XVI e XVII, buscava forças produtivas, não as encontrando nos insanos. A esse "fenômeno geral de dominação da classe burguesa" poderse-ia, ao invés, procurar ramificações dessa exclusão no seio da família, da medicina, da polícia etc. (FOUCAULT, Cours du 14 janvier 1976, DE, III, 1994, p. 182).

Portanto, não ter delimitado essa questão em um conjunto teórico específico, conceitual, não o exime de ter inovado a maneira de compreendê-lo, pelo contrário. Assim, a sua "analítica do poder" (termo mais apropriado do que "conceito de poder") se estende por toda a obra, abarcando temas como "Biopoder, Biopolítica, Disciplina, Governo, Liberalismo, Luta, Medicalização, Panóptico, Polícia e Razão de Estado" (CASTRO, 2009, p. 323). Sem que se precise refazer todo esse caminho foucaultiano, reservamos esta parte da tese para mostrar um pouco a constituição funcional desse poder, 
concentrando logo após em dois aspectos: em um poder ancorado em muito nas ciências e, depois, na necessidade de haver, em nossa sociedade, uma "circulação" desse poder, que vai estender-se às instituições educacionais e ao problema da "norma", linha mestra que percorrerá todo esse processo.

Em 1977 Foucault diz: "É o problema de que determina quase todos os meus livros: como, nas sociedades ocidentais, a produção de discursos mudam (ao menos por um tempo determinado) de um valor de verdade ligado aos diferentes mecanismos e instituições de poder?" (FOUCAULT, "Séxualité et verité", DE III, 1994, p. 137). Em síntese, o que procura Foucault é transferir a pesquisa sobre o poder do lado do "edifício jurídico da soberania", dos aparelhos de Estado ou das ideologias, para uma "análise do lado da dominação [...] dos operadores materiais, das formas de sujeitamento, do lado das conexões e utilizações dos sistemas locais desse sujeitamento, do lado, enfim, dos dispositivos de saber" (FOUCAULT,Cours du 14 janvier 1976, DE, III, 1994, p. 184). Diz Foucault textualmente:

Para conduzir a análise concreta das relações de poder é necessário abandonar o modelo jurídico da soberania [que implica pensar] o indivíduo como sujeito de direitos naturais ou de poderes primitivos. Imagina-se aí sujeitos ideais que, espontaneamente, cedem seus direitos em favor da coletividade ou de uma convivência comum, o que quer dizer, que se sujeitam livremente. (FOUCAULT, "Il faut défendre la société", DE, III, 1994, p. 124). 
Foucault tenta inverter isso: é preciso ver "como as relações de sujeitamento podem fabricar sujeitos". Quando se pensava na relação poder-soberania, seja ela monárquica ou democrática, buscava-se inscrevê-la no âmbito do "direito de punir". Ao invés disso, é preciso ver como esse direito está instalado ou atravessa os corpos nas instituições locais, regionais, materiais. O lugar jurídico do exercício do poder deve cada vez mais ser deixado de lado a favor da disseminação disso no amplo horizonte das instituições sociais (FOUCAULT, Cours du 14 janvier 1976, DE, III, 1994, p. 178). Embora ele em $A$ ordem do discurso (1996) tenha se referido a um poder na sua concepção tradicional, ou seja, como "mecanismo essencialmente jurídico", o que diz a Lei e o que ela interdita - repressão, portanto, como usou em Histoire de la folie (embora tenha achado esse tratamento pertinente, se se considerar que o caso da loucura foi, em grande medida, tratado a partir de formas de exclusão) - ao estudar a penalidade, em Surveiller et punir, convenceu-se de que não era "realmente em termos de direito, mas em termos de tecnologia, em termos de tática e de estratégia" que as relações de poder deveriam ser analisadas ("Les rapports de pouvoir passent à l'intérieur des corps", DE, III, p. 229). A partir do séc. XIX até a loucura passou a ter um tratamento "positivo" relativamente ao poder, ao inserirse em uma "grande tecnologia da psique" (FOUCAULT, "Les rapports de pouvoir passent à l'intérieur des corps", DE, III, 1994, p. 230).

Dessa forma, ao reportar-se ao Direito ele "não pensa simplesmente na lei, mas no conjunto de aparelhos, insitituições, regulamentos, artigos de lei"; da mesma forma ao dizer dominação ele se refere "a múltiplas formas de dominação que podem se exercer no interior da sociedade. Não, pois, o rei na 
sua posição central, mas sujeitos em suas relações recíprocas; não a soberania no seu edifício único, mas os sujeitamentos múltiplos que têm ligação ou que funcionam no interior do corpo social"' (FOUCAULT, Cours du 14 janvier 1976, DE, III, 1994, p. 178). Juntando um e outro chega-se a uma interpretação do Direito "não do lado de uma legitimidade a fixar, mas do lado de procedimentos de sujeitamentos que ele põe em obra" (FOUCAULT, Cours du 14 janvier 1976, DE, III, 1994, p. 178). Diz ele aí que, no lugar de se fazer aparecer a soberania e a obediência, seria preciso pôr em jogo "o problema da dominação e do sujeitamento".

O que se precisa fazer é analisar as "técnicas e táticas de dominação", e os locais onde estas se ancoram. E uma dessas ancoragens esteve ligada à "história da verdade" que, para o Foucault desde os idos de 1974, esteve atrelada no Ocidente a dois caminhos: um, à história das ciências (viu-se anteriormente a sua menção elogiosa a Canguilhem, autor que não compactuava com uma visão rígida de saber científico, mas faltava dizer algo acerca do estatuto da ciência como tal); a outra, a "regras de jogo a partir das quais se vê nascer certas formas de subjetividade, certos domínios de objetos, certos tipos de saber" ("De la nature humaine: justice contre pouvoir", DE, I, 2001, p. 1348).

Todas essas análises são pautadas por mediações históricas, daí podendo-se tirar algumas conclusões. Foucault aponta que nos séculos XVII e XVIII é que surge uma nova mecânica de poder, o poder disciplinar: no lugar de um poder exercido sobre a terra e seus produtos - onde a teoria da soberania esteve instalada (embora vá permanecer como "ideologia do direito") - o novo poder disciplinar será exercido sobre o corpo. E se Michel Foucault diz que "O discurso da disciplina 
é estranho àquele da lei" é porque "As disciplinas vão portar um discurso que será aquele da regra, mas não da regra jurídica derivada da soberania; elas portarão um discurso da regra natural, quer dizer, da norma", tanto se referindo menos ao Direito do que ao campo das ciências humanas, quanto a "sua jurisprudência", o saber clínico (FOUCAULT, Cours du 14 janvier 1976, DE, III, 1994, p. 188). “O desenvolvimento da medicina, a medicalização geral do comportamento, das condutas, dos discursos, dos desejos", tudo isso termina se reencontrando com dois traços heterogêneos, o da "disciplina e da soberania" (FOUCAULT, Cours du 14 janvier 1976, DE, III, 1994, p. 188). Assim, as "peças constitutivas dos mecanismos gerais do poder em nossa sociedade" são o direito da soberania e a mecânica disciplinar (FOUCAULT, Cours du 14 janvier 1976, DE, III, 1994, p. 189). ${ }^{47}$

Nas sociedades ocidentais a linguagem do poder é o Direito, ao invés da magia ou da religião (FOUCAULT, “Le jeu de Michel Foucault", DE, III, 1994, p. 305). Para que a burguesia se desembaraçasse do poder monárquico foi preciso valer-se do discurso jurídico, do discurso do Direito; e essa foi uma das razões pelas quais durante tanto tempo se esteve preso a uma concepção jurídica do poder, um poder que

47 É proveitoso lembrar aqui da tese de doutorado de Marcio Alves da Fonseca. Segundo ele, em Michel Foucault e o Direito (2002, p. 30 e 242), houve três figuras foucaultianas relativas à relação direito-norma: "a perspectiva de uma primeira oposição entre direito e normalização, a perspectiva de uma implicação entre direito e normalização e a perspectiva de uma nova oposição (não conceitual) entre direito e normalização". Quanto à perspectiva última, ela visaria a "interrogar sobre a possibilidade de práticas ligadas ao direito que possam representar uma forma de resistência ao poder normalizador", direção que será adotada no Capítulo IV desta tese. 
diz não, da proibição, daquilo que cerceia, que diz respeito à lei, à regra, ao soberano, à delegação de poder - tudo isso indo à contramão de uma noção real do funcionamento do poder. Daí buscar-se pensar não no poder, mas em poderes, localizando-os "em sua especificidade histórica e geográfica", vendo que eles, ao invés de buscarem dizer não, buscam "ser produtores de uma eficiencia, de uma aptidão, produtores de um produto", (FOUCAULT, "Les mailles du pouvoir", DE, IV, 1994, p. 186-187).

Porém, achando o Direito algo "inadequado", "irreal" e "abstrato", o que o interessou foi aquilo que se mostrava como "extrajurídico": o sujeito classificado como normal ou anormal, suas pulsões agressivas identificadas - enfim, deslocamento que ia do plano jurídico ao plano médico (FOUCAULT, "Le pouvoir, une bête magnifique", DE, III, 1994, p. 378). Ou, se se quer, do plano jurídico para o plano "científico". Em "Questions à Michel Foucault sur la géographie" (FOUCAULT, DE, III, 1994, p. 29) Foucault diz ser contra filosofias que visam a um "discurso de verdade sobre não importa qual ciência". O projeto positivista caracterizou-se por buscar as leis dos fenômenos. Ele, ao contrário, sempre pensou em "como a verdade na história pode ter politicamente o seu efeito", sempre pensou menos no ideal de verdade do que nos "combates" dentro do palco da história, sendo tal questão anterior mesmo às críticas aos positivistas, não atentos à delimitação e observância das peculiaridades existentes entre ciências humanas e naturais.

Daí Foucault ter falado, nessa perspectiva, sobre a medicina, psiquiatria e penalidade, e jamais pretender fazer uma "história geral das ciências humanas, nem fazer uma crítica em geral da possibilidade das ciências. O subtítulo de As palavras e 
as coisas não é a arqueologia, mas uma arqueologia das ciências humanas" (FOUCAULT, “Questions à Michel Foucault sur la géographie", DE, III, 1994, p. 29). Inspirando-se novamente em Nietzsche, a pergunta a ser feita é: “Não mais: qual é o caminho mais seguro da verdade? Mas, qual foi o caminho casual da verdade?" (FOUCAULT, "Questions à Michel Foucault sur la géographie", DE, III, 1994, p. 31). Está-se assim falando acerca da coação do verdadeiro. $\mathrm{O}$ que significa dizer que cada sociedade tem sua política geral da verdade ou seu regime de verdade? Que existem os discursos que "ela acolhe e faz funcionar como verdadeiro" (FOUCAULT, "La fonction politique de l'intellectuel", DE, III, 1994, p. 112). Na nossa sociedade Foucault diz haver "cinco traços historicamente importantes":

A 'verdade' está centrada sobre a forma do discurso científico e sobre instituições que o produzem; ela está submetida a uma constante incitação econômica e política (necessidade de verdade tanto para a produção econômica quanto para o poder político); ela é objeto, sob formas diversas, de uma imensa difusão e consumo (ela circula nos aparelhos de educação ou de informação dont l'étendue é raltivamente largo no corpo social, malgrado algumas limitações estritas); ela é produzida e transmitida sob o controle não exclusivo mas dominante de alguns grandes aparelhos políticos ou econômicos (Universidade, armée, écriture, médias); enfim, ela é a entrada de todo um debate político e de todo um afrontamento social (lutas 'ideológicas") (FOUCAULT, "La fonction politique de l'intellectuel", DE, III, 1994, p. 113, grifo nosso). 
Ora, quando Foucault analisou o problema da loucura, sua interrogação foi no sentido de saber "como e por que o discurso científico sobre a loucura apareceu naquele momento, ou seja, em suma, após o fim do século XVII" (FOUCAULT, “De l'archéologie à la dynastique”, DE, I, 2001, p. 1278). A pergunta foucaultiana não busca pensar, por exemplo, nas iniciativas da ciência em depurar o seu corpo teórico, pressupondo-se neste caso avançar no problema do conhecimento e da verdade. Na entrevista de Michel Foucault acima, datada de 1973, a sua conclusão mais proeminente é a de que na nossa cultura "saber e poder estão profundamente ligados" (FOUCAULT, “De l'archéologie à la dynastique", DE, I, 2001, p. 1282).

Nesse sentido, se a pergunta primeira acerca da ciência não deve ser aquela voltada para o seu estatuto epistemológico, é porque se trata de compreender o que, qualificando esta ou aquela disciplina como científica, tal saber então legitimado buscará desqualificar outros tantos (FOUCAULT, “Cours du 7 janvier 1976", DE, II 1994, p. 166). No "Cours du 7 janvier 1976" (FOUCAULT, DE, II 1994, p. 163) Foucault aborda a ideia de crítica, geralmente entendida como "uma espécie de produção teórica autônoma", e cada vez mais ligada à necessidade de um 'retorno ao saber' ou 'retorno ao conhecimento' daqueles que operam o movimento crítico. Ora, o que pode se ver aí, contudo, é a necessidade foucaultiana de fazer aparecer a "insurreição dos 'saberes sujeitados'". Teria se valido a "crítica" do aparecimento de uma sociologia da delinqüência, ou do aparecimento "de conteúdos históricos que permitiram fazer, tanto do asilo quanto da prisão, a crítica efetiva”? (FOUCAULT, “Cours du 7 janvier 1976", DE, II 1994, p. 163)? 
A opção foucaultiana é pelo segundo ponto, concluindo em seguida que "só os conteúdos históricos podem permitir reencontrar a clivagem dos afrontamentos e das lutas que os ordenamentos funcionais ou as organizações sistemáticas têm por tarefa justamente, mascarar" (FOUCAULT, "Cours du 7 janvier 1976", DE, II 1994, p. 163). Daí se vê como fica clara a ideia de um saber sujeitado: primeiro, ele se instala de forma mascarada "no interior dos conjuntos funcionais e sistemáticos", cabendo à crítica buscar fazer reaparecer essas máscaras.

É preciso, portanto, identificar essa "máscara" construída em torno da ciência, fazendo com que o saber apareça envolto em "idealidades": que haja divisão entre "homens do poder e homens do saber"; que estes "devem renunciar a todo poder, renunciar a toda participação na cidade para adquirir a verdade". Em suma, Foucault defende a ideia de que há um "apetite gigantesco de poder" no Ocidente, infiltrado nas malhas do saber (FOUCAULT, "De l'archéologie à la dynastique", DE, I, 2001, p. 1282). ${ }^{48}$

Aquelas duas tendências da história do conhecimento (falado no tópico sobre a verdade), salvar o sujeito e a verdade, deram

[...] um certo romantismo à história da ciência: solidão do homem de verdade, originalidade que reencontrava a origem para a história e malgrado esta. Eu penso que, mais fundamentalmente, trata-se

48 Daí, conclui ele na página seguinte, como o Marxismo pudera ter almejado ser um instrumento de análise e de luta apartado desse apetite pelo poder, que busca vigiar e controlar? 
de sobreimpor teoria do conhecimento e sujeito do conhecimento sobre a história do conhecimento (FOUCAULT, "De la nature humaine: justice contre pouvoir", DE, I, 2001, p. 1349).

Nesse sentido, há de se explicar como a mudança teórica em relação a algo se modifica "sem passar por um 'inventor' original que descobre a "verdade'"; em segundo lugar, "devese mostrar como o funcionamento das regras de compreensão pode produzir em um indivíduo um conhecimento novo e inédito" (FOUCAULT, "De la nature humaine: justice contre pouvoir", DE, I, 2001, p. 1350).

A “cientificidade" de algo tem a ver "com um número de regras que vão definir a aceitabilidade ou a gramaticidade dos enunciados"; daí a criação ou inventividade serem apenas instâncias "possíveis" dentro do quadro de saber existente, e essa consciência é manifestada por Michel Foucault, quer dizer, a consciência de que, quando ele pensa estar falando algo de novo, fá-lo na medida da sua inserção em um horizonte lingüístico e epistemológico no qual ele mesmo transita (FOUCAULT, "De la nature humaine: justice contre pouvoir", DE, I, 2001, p. 1352-1353).

Mas quer-se frisar aqui o seu alvo às ciências, mesmo às naturais. Para Foucault, uma simples caracterização científica dos biólogos, como a classificação dos animais e das plantas, passara por diferentes regras: simbolismo, história natural, anatomia comparativa, teoria da evolução - e "Cada vez essa reescritura torna o saber completamente diferente em suas funções, sua economia, suas relações internas" (FOUCAULT, "De la nature humaine: justice contre pouvoir", DE, I, 2001, 
p. 1355). Acrescente-se a isso que, em tal horizonte, leva-se em conta o contexto econômico, técnico, político e sociológico imperante.

Pensar dessa forma significa acatar a ideia de que um determinado saber não corresponde a algo como uma retirada do véu do erro ou ignorância, que há todo um contexto externo que a determina. Em uma palavra, que há comprometimentos sérios do saber científico com o momento histórico em que ele vive, e Foucault dá alguns exemplos acerca disso. Tomando o conceito biológico de "degenerescência" como alvo, este não teria representado um caso particular de ideologia científica racista? Por isso Foucault dizer que "O racismo não foi de início uma ideologia política"; que o antisemitismo moderno começou com aquele conceito, nascido no âmago da ciência biológica (FOUCAULT, "Le jeu de Michel Foucault", DE, III, 1994, p. 324-325).

Ao pensar no surgimento de algumas outras ciências, como a demografia e a estatística, como não ver que elas apareceram, a partir do século XVIII, atreladas a conjunturas sócio-econômicas, os "fenômenos de população", quando começam a ganhar destaque a questão das epidemias, das condições de habitat e de higiene das pessoas, implicando no funcionamento da sociedade liberal burguesa? Ciência e poder aí se atrelaram, pois, formando a "biopolítica" ou "biopoder", e isso mostra o linque com a criação de ciências. ${ }^{49}$

49 Para ele a biopolítica foi a maneira pela qual ele tentou, "após o século XVIII, racionalisar os problemas colocados à prática governamental pelos fenômenos proprios a um conjunto de viventes constituídos em população: saúde, higiene, natalidade, longevidade, raças..." (FOUCAULT, “Naissance de la biopolitique”, DE, III, 1994, p. 818). 
Afinal, pensando agora no fenômeno da loucura, como não concordar que ela, tendo se tornado um objeto de estudo, nasceu de uma "situação econômica e social particular" vivida pelo Ocidente (FOUCAULT, "De la nature humaine: justice contre pouvoir", DE, I, 2001, p. 1357)? Para Michel Foucault, isso responde melhor à questão do surgimento dos saberes, do que uma explicação voltada para as descobertas feitas pelos grandes gênios e inventores, rumo a uma apreensão do real cada vez mais objetivada e posta a nu (FOUCAULT, "De la nature humaine: justice contre pouvoir", DE, I, 2001, p. 1358).

A ligação entre saber e poder em Histoire de la folie viu na prática psiquiátrica sua ligação com instituições, exigências econômicas, urgência de decisões políticas de regulações sociais etc. (FOUCAULT, "Entretien avec Michel Foucault", DE III, 1994, p. 141). Essas disciplinas, portanto, como no seu estudo sobre a Medicina (FOUCAULT, 2003b), são engajadas "muito profundamente nas estruturas sociais" (FOUCAULT, “Entretien avec Michel Foucault", DE III, 1994, p. 141), daí não se falar apenas em estruturas epistemológicas:

O que está em questão é o que rege os anunciados e a maneira pelas quais ele se regem uns e outros para constituir um conjunto de proposições aceitáveis cientificamente e suscetíveis, por conseguinte, de ser verificadas ou invalidadas pelos procedimentos científicos. Problema em suma de regime, de política do enunciado científico. Nesse nível, trata-se desaber não qual é o poder que pesa do exterior sobre a ciência, mas quais efeitos de poder circulam entre os enunciados científicos (FOUCAULT, "Entretien avec Michel Foucault", DE III, 1994, p. 144, grifo nosso). 
Perguntar como funcionava a loucura em uma sociedade como a nossa significava perguntar por esse discurso que tem o estatuto e a função de discurso de verdade, a saber, o discurso científico, mas, ao mesmo tempo, fugindo do círculo epistemológico preso à dicotomia verdade-erro (FOUCAULT, “Le jeu de Michel Foucault", DE, III, 1994, p. 312). E mesmo que as ciências se transformem e se encontrem justificativas plausíveis para pensar que poderia tratarse de um fenômeno evolutivo na ceara do conhecimento, o interesse foucaultiano era distinto, consistindo em "saber quais eram os grupos de transformações necessárias e suficientes no interior do regime mesmo dos discursos para que se possam empregar essas palavras aí antes do que aquelas" (FOUCAULT, “Le jeu de Michel Foucault”, DE, III, 1994, p. 314). Não era seu objetivo fazer uma apologia à descontinuidade, mas entender como um regime de saber ou uma ordem de saber podia mudar (FOUCAULT, "Entretien avec Michel Foucault", DE III, 1994, p. 141). Ou seja, não buscando ver apenas possíveis "mudanças de conteúdo", quando "antigos erros" se substituem a "novas verdades", ou ainda pensar o fenômeno como possíveis mudanças paradigmáticas, como em Kuhn (1991).

A análise arqueológica foucaultiana, acrescentando talvez algo mais do que se viu no primeiro capítulo, buscou analisar as práticas discursivas "em suas regras internas e em suas condições de aparição"(FOUCAULT, "Entretien avec Michel foucault", DE, IV, 1994, p. 72); buscou ainda colocar problemas de forma "rigorosa", "precisa" e "séria", ou seja, "justamente em suas formas mais singulares e mais concretas", embora assim fazendo possa-se estar inserido em problemas gerais; afinal, "o que há de mais geral em uma sociedade do 
que a maneira pela qual ela define sua relação com a loucura?" (FOUCAULT, “Entretien avec Michel foucault", DE, IV, 1994, p. 84). Em resumo:

Enquanto que os historiadores das ciências, na Franca, se interessaram essencialmente pelo problema da constituição de um objeto científico, a questão que eu me pus era esta: como se faz que o sujeito humano se dê a si mesmo como um objeto de saber possível, através de quais formas de racionalidade, através de quais condições históricas e finalmente a qual preço? (FOUCAULT, "Structuralisme et poststructuralisme", DE, IV, 1994, p. 442).

Em outro momento ele diz:

[...] meu problema foi saber se não seria possível fazer uma história das ciências que tente recuperar o nascimento, o desenvolvimento, a organização de uma ciência não realmente a partir de suas estruturas racionais internas, mas a partir dos elementos exteriores que puderam justamente lhe servir de suporte (FOUCAULT, "La scène de la philosophie", DE, III, 1994, p. 583).

Ora, se as "práticas discursivas", como os discursos científicos, não podem ser entendidas como mera "fabricação de discursos", é porque elas "tomam corpo nos conjuntos técnicos, nas instituições, nos esquemas de comportamento, nos tipos de transmissão e de difusão, nas formas pedagógicas 
que ao mesmo tempo as fixam e as mantêem (FOUCAULT, "La volonté de savoir", DE, I, 2001, p. 1109, grifo nosso). Inegalvelmente a educação pode ser compreendida como um aporte fundamental a essa difusão do conhecimento. Seguindo o fio condutor do parágrafo inicial desta parte temática da tese, o prolongamento das críticas endereçadas à ciência precisará tocar, pois, nesse aspecto. Duas perguntas devem ser respondidas: primeiro, qual tipo de difusão do conhecimento a educação em geral, mas focando na universitária (em tese uma instância privilegiada de pesquisa e produção de saber e tecnologia), busca perpetuar? Segundo, como pode surgir aí um pensar crítico, caso a resposta da primeira questão tocar no âmbito da busca de processos normalizantes?

A tentativa a seguir é investigar os poucos momentos em que Michel Foucault se refere à educação, sobretudo nas vezes em que aparece nos Dits et écrits. Porque, como escreveu Gadelha,

[...] embora fiquemos com a impressão de que a educação pareça estar sempre ali, em alguma medida presente, implicada no funcionamento das disciplinas, do dispositivo da sexualidade, do poder pastoral, dos processos de normalização, de regulamentação da vida das famílias pobres, da organização da produção, no mais das vezes, essa pesença parece discreta, aparecendo como tema/questão coadjuvante, cumprindo como que um papel secundário em face de outros mecanismos ou dispositivos de regulação e controle da vida do corpo-espécie da população (GADELHA, 2009, p. 172). 
Sem perder de vista a rarefação dos estudos foucaultianos relativos à educação, não obstante, sob a lente da história algumas datas são importantes para ele no tocante a essa temática. Foucault identifica no século XV e início do XVI o aparecimento de uma preocupação ocidental com ela de maneira bem específica. Com o desenvolvimento do capitalismo, a educação vai incorporando as tendências de disciplinarização e de normalização da existência (FOUCAULT, "Le pouvoir, une bête magnifique", DE, III, 1994, p. 375), e o grande problema da pedagogia que aparece é o do governo das crianças (FOUCAULT, “La 'governamentalité'”, DE, III, 1994, p. 636).

Em "De la nature humaine: justice contre pouvoir" (FOUCAULT, DE, I, 2001, p. 1361) Foucault estabelece uma relação necessária entre educação e política. Primeiro, diz ele, "A essência da nossa vida é feita, antes de tudo, do funcionamento político da sociedade na qual nos encontramos". Ora, o sistema escolar só aparentemente visa à distribuição do saber; sua pretensão velada é contribuir para a manutenção de certa classe social, excluindo outras, e é precisamente este o papel político que se deve exercer em uma sociedade como a nossa: "criticar o funcionamento das instituições aparentemente neutras e independentes" (FOUCAULT, "De la nature humaine: justice contre pouvoir", DE, I, 2001, p. 1364).

Isso tem a ver com um ponto de partida foucaultiano acerca dos procedimentos básicos da nossa sociedade. Recusando o questionamento da sociologia tradicional, voltado para o aspecto de como a nossa sociedade cria a coesão entre os homens, a postura de Michel Foucault foi ao sentido inverso: "através de qual sistema de exclusão [...], através de qual jogo de negação e de rejeição a sociedade pode começar a funcionar" (FOUCAULT, “Á propos de la prison d'Attica", DE, I, 2001, p. 1395-1396)? 
Eduação e poder, dessa forma, aproximam-se a cada instante, e o coroamento desses elementos encontra as táticas e estratégias de poder (FOUCAULT, “Michel Foucault, o ilegalismo e a arte de punir", DE, III, 1994, p. 87). Em “Des questions de Michel Foucault à 'Hérodote'” ele diz que o termo estratégia é importante quando se quer estudar o saber e suas relações com o poder e que a necessidade de constituir um espaço de saber reservado à ciência tem uma razão: "A partilha entre ciência e saber não científico é um efeito de poder ligado à institucionalisação dos conhecimentos na Universidade, centros de pesquisa etc." (FOUCAULT, DE, III, 1994, p. 94-95). ${ }^{50}$

Outro problema relativo à educação é a sua colocação como instância detentora de uma suposta prerrogativa de confiscar o "direito de falar", assim como ocorreu com a administração e os seus reformadores no caso da instituição prisional (FOUCAULT, “Les intellectuels et le pouvoir”, DE, I, 2001, p. 1181). Em “Table ronde" (DE, I, 2001, p. 1199) Michel Foucault vê o trabalho social inscrito "no interior de uma grande função", a saber, vigiar e corrigir os indivíduos, "ou seja, puni-los ou pedagogisá-los". E se se fala em trabalhadores sociais, a hipótese de Foucault, a pergunta que ele faz é se sua origem não deriva da função do educador, "o 'instrutor' propriamente dito” (FOUCAULT, DE, I, 2001, p. 1199), apontando para um paradoxo específico: ora, entendendo o papel do intelectual, na melhor das hipóteses, como alguém capaz de diagnosticar o presente, como fica isso se os próprios trabalhadores sociais

50 Outro exemplo dessas táticas de poder é quando a sociedade burguesacristã no século XIX fez do sexo um pecado; ora, ligado a fins econômicos, deve-se preferir o trabalho ao prazer, à reprodução da forças do que à sua dispersão (FOUCAULT, "L'Occident et la vérité du sexe", DE, III, 1994, p. 103). 
terminam representando o papel do instrutor e do professor secundário, nascendo, não obstante, daqueles intelectuais? Eis a "grande traição dos intelectuais com relação [pois mancomunado] ao estado burguês" (FOUCAULT, "Table ronde", DE, I, 2001, p. 1199). ${ }^{51}$

Nesse sentido, como pensa Foucault, a Universidade se assemelha aos ritos de passagem existentes nas sociedades primitivas. Nesse texto de 1972 Foucault vê a Universidade hoje diferente da do século XIX; nesta, "o ensino superior era exclusivamente reservado às crianças da burguesia", ou a "essa franja da pequena burguesia", reserva de mão-de-obra necessária à indústria e ao desenvolvimento científico e técnico. Como as Universidades de hoje acolhem estudantes de classes econômicas mais inferiores ("em vias de proletarização"), o "estatuto da Universidade torna-se problemático". Entenda-se isso direito: para Michel Foucault a nossa sociedade sempre buscou "rejeitar" ou "excluir" coisas - e tal foi o estudo que ele empreendeu, o que era do "seu interesse". Uma "primeira função da Universidade [é, portanto,] colocar os estudantes fora de circulação. Sua segunda função, entretanto, é integradora: uma vez que um estudante passou seis ou sete anos de sua vida nessa sociedade artificial, ele se torna assimilável: a sociedade pode consumi-lo"; ele recebe "insidiosamente" valores, modelos de conduta socialmente desejáveis, "formas de ambição e elementos de um comportamento político" (FOUCAULT, “Conversation avec Michel Foucault, DE, I, 2001, p. 1052).

51 Por exemplo, aprende-se que a luta social deve ser feita através da justiça burguesa, preferindo o juiz a uma vingança. Sobre isso um dos trabalhos de maior fôlego de Michel Foucault foi "Sur la justice populaire. Débat avec les mãos" (DE, I, 2001, p. 1208). 
Ambigüidade das funções universitárias, portanto: elas devem continuar sendo um meio de exclusão, mas, por outro lado, engendram inimigos internos, estudantes aqui ou ali com um potencial revolucionário (FOUCAULT, "Conversation avec Michel Foucault, DE, I, 2001, p. 1053). E a crítica que eles fazem vão além dos teóricos, historiadores ou "arquivistas". Os estudantes é que se tornam os "seus próprios arquivistas". Isso tem a ver com a "maneira pela qual as sociedades transmitem o saber", inseridas em um "sistema complexo" e não ainda "plenamente analisado" (FOUCAULT, "Conversation avec Michel Foucault, DE, I, 2001, p. 1051). Esses estudantes se colocam na posição de eventuais "transgressores", e isso se alinha à perspectiva foucaultiana: menos fornecer um "remédio" para os problemas educacionais do que a abertura de um horizonte de transgressão e de "estímulo" para contra-investidas não institucionais (VEIGA-NETO, 2005, p. 18).

Falando sobre o ensino na França - pois ele diz não conhecer muito o sistema americano, embora acredite ser "sem dúvida" diferente - acha que o professor universitário, por seu status de funcionário público, "perpetua o sistema de transmissão do saber que exige o governo, ou seja, a classe burguesa, cujos interesses são representados pelo governo". A "marcha livre" de um ensino universitário exigiria fazer deste lugar algo diferente daquele que simplesmente "aceita os valores que lhe são impostos", mas essa "marcha" parece ser menos uma vocação universitária do que uma tensão vivida neste meio, face às exigências veladas da burguesia nesses novos tempos.

Mostrando que uma análise crítica precisa assenhorear-se das peças do jogo que estão dispostas sobre a mesa, quanto 
aos estudantes mesmos há de se observar a relação deles na França com a influência exercida, primeiro, pelo conservadorismo do partido comunista: "O partido comunista aceita e perpetua a maior parte dos valores burgueses (na arte, família, sexualidade, na vida cotidiana em geral). As pessoas devem se libertar desse conservadorismo cultural, tanto quanto do conservadorismo político" (FOUCAULT, "Conversation avec Michel Foucault, DE, I, 2001, p. 1056-1061).

Uma segunda grande influência vem da C.G.T (a central dos trabalhadores), embora na América se conviva com a questão racial mais fortemente do que na França. Neste país, diante de dois modelos disponíveis - o americano e o russo o partido comunista "impôs" o segundo, e a nova luta travada é, primeiro, contra essa influência massiva e, segundo, contra o "chauvinismo cultural" existente, manifestado na França pela pouca tradução de livros americanos. Enfim, "Nós não devemos permitir que a luta contra a influência e as relações econômicas com os Estados Unidos afete nossas relações com os intelectuais americanos" (FOUCAULT, "Conversation avec Michel Foucault, DE, I, 2001, p. 1056-1057).

Falando sobre Maio de 68 na França, diz ter entendido o slogan de morte à Universidade no seu sentido mais superficial, ou seja, àquela universidade modelar do século XIX, preocupada em formar uma elite social burguesa. Mas a tarefa não é pequena: "restam os grandes mecanismos secretos pelos quais uma sociedade transmite seu saber e se transmite ela mesma sob a aparência do saber: eles estão sempre aí, jornais, televisão, escolas técnicas, e os liceus mais ainda do que a Universidade" (FOUCAULT, "Par-delà le bien et le mal", DE, I, 2001, p. 1097). 
Mas tudo não se passa ao abrigo da razão. Ao contrário, é ela mesma que se liga, antes de tudo, a algo que tem a ver com um duplo movimento: codificação/prescrição, de um lado, e formulação do verdadeiro e do falso, do outro (FOUCAULT, “Table ronde du 20 mai 1978", DE, IV, 1994, p. 26). As "práticas" cotidianas são a mistura de códigos que"

\begin{abstract}
[...] regulam maneiras de fazer (que prescrevem como escolher as pessoas, como as examinar, como classificar as coisas e os signos, como adestrar os indivíduos etc.) e uma produção de discursos verdadeiros que servem de fundamento, de justificação, de razões de ser e de princípio de tranformações dessas mesmas maneira de fazer. Para dizer as coisas claramente: meu problema é saber como os homens se governam (eles mesmos e os outros) através da produção de verdade (FOUCAULT, "Table ronde du 20 mai 1978", DE, IV, 1994, p. 26);
\end{abstract}

Antes do século XIX a sociedade Ocidental se apresentava como "sociedades de direito, com parlamentos, legislações, códigos, tribunais"; a partir do século XIX, ao contrário, nasce

[...] todo um outro mecanismo de poder que se infiltrava, que não obedece a formas jurídicas e que não tinha por princípio fundamental a lei, mas antes o princípio da norma, e que tinha por instrumento não mais os tribunias, a lei e o aparelho judiciário, mas a medicina, os controles sociais, a psiquiatria, a psicologia. Nós estamos pois em um mundo disciplinar, nos estamos em um mundo da regulação 
[...], nós vivemos em um sociedade onde o crime não é mais simplesmente a transgressão da lei, mas antes o desvio com relação à norma", entendendo por esta algo que vai além de um "plano jurídico (FOUCAULT, "Les mailles du pouvoir", DE, IV, 1994, p. 199).

Assim, se juristas e advogados falam de norma e disciplina, é que antes eles "são obrigados a empregar esse vocabulário". Entre a nova tecnologia do poder que se desenvolve no capitalismo, Foucault diz haver uma "implicação permanente" de ambos: se o primeiro faz parte do segundo, este só pode se desenvolver utilizando-se daquele (FOUCAULT, “Les mailles du pouvoir", DE, IV, 1994, p. 200). Em outras palavras, se o poder não apenas reprime, se ele faz algo mais a não ser criar a Lei, é porque visa a algo muito mais ínfimo e geral: engendrar, por todos os cantos, processos de normalização dos sujeitos, a saber, de seus pensamentos e de suas condutas, seja ao nível individual, através das disciplinas, seja ao nível da população, através do biopoder.

Quanto às disciplinas, tratadas por Foucault de maneira detalhada em Surveiller et Punir (2003f), ele toma o cuidado de diferenciar uma sociedade disciplinar e uma sociedade disciplinada; nesta última, estar-se-ia falando, como em Weber, de um "tipo ideal": o homem disciplinado. A sociedade disciplinar, ao contrário, tomando corpo a partir do século XVIII em diante, quando se formam aos poucos o capitalismo e as indústrias, inaugurou uma tecnologia do adestramento, da vigilância do comportamento e da "individualisação dos elementos do corpo social" (FOUCAULT, "Introduction", DE, IV, 1994, p. 13). Ela doravante vai percorrer as grandes 
fábricas, o exército, as escolas, sendo algumas das suas características importantes: 1- ser "Uma arte de repartição espacial dos indivíduos", a fim de obter uma máxima eficácia; 2 - um controle visando não o resultado, mas o desenvolvimento de uma ação; 3 - uma técnica de poder, implicando uma "vigilância constante e perpétua dos indivíduos"; e 4 - supõe registros permanentes, ou anotações periódicas e comunicação de informações para os escalões superiores.

A disciplina é uma técnica de poder que busca obter como resultado a "singularização dos indivíduos. É o poder de individualização cujo instrumento fundamental reside no exame" (FOUCAULT, "L'incorporação do hospital na tecnologia moderna", DE, III, 1994, p. 517). Em outro momento Michel Foucault se torna mais claro acerca da relação disciplina-individuação: "[...] como vigiar alguém, como controlar sua conduta, seu comportamento, suas aptidões, como intensificar sua performance, multiplicar suas capacidades, como colocá-lo onde ele será mais útil" (FOUCAULT, "Les mailles du pouvoir", DE, IV, 1994, p. 186-192)?

E, embora a disciplina não tenha sido apagado na démarche posterior de Michel Foucault, é incorporado a um outro mecanismo mais geral: o da norma.Como escreve Castro (2009, p. 309), a Lei diz respeito a condutas de indivíduos presas "a um corpus de códigos e de textos"; a qualificações dos atos individuais como "permitidos ou proibidos"; busca, a partir daí, a condenação; e, por fim, fica restrita a esse âmbito legal, não tendo uma "exterioridade" além da Lei. A norma é muito mais abrangente: ela se situa em um campo de "comparação" e de "diferenciação" entre os indivíduos, onde a norma comumente estabelecida é o optimum a que se pode e deve chegar; não se atendo ao permitido ou proibido, "A norma mede 
em termos quantitativos e hierarquiza em termos de valor a capacidade dos indivíduos", valorizando as condutas tanto quanto elas consigam conformar-se aos padrões, homogeneizando os indivíduos; por fim, a sua "exterioridade" é o limite traçado entre o normal e o anormal, ou entre o normal e o patológico, como no caso da medicina, "ciência régia" dessa relação (FOUCAULT, apud CASTRO, 2009, p. 310). ${ }^{52}$

A preocupação com o tema da norma, para autores de referência importantes do pensamento de Michel Foucault, como Pierre Macherrey, demarcaria mesmo uma linha mestra que percorre todos os momentos foucaultianos acima falado, ligando-o a autores como Canguilhem. Para Macherrey (2009), tomando a psiquiatria como exemplo, ao mostrar, com Foucault, que ela descende do inquisidor, com suas técnicas de marcação, de diagnóstico ou de interrogatório, busca o entendimento segundo o qual o poder da lei em nossa sociedade está "se integrando a um poder muito mais geral: grosseiramente, aquele da norma", quer dizer, cessando de "ser uma sociedade jurídica articulada essencialmente sobre a lei", tornando-se uma sociedade "articulada sobre a norma". Como no exemplo do crime, busca-se entendê-lo como uma doença, cuja condenação passa por procedimentos ou "prescrições terapêuticas", ou seja, a medicina, como ciência do normal e do patológico, "vai ser a ciência rainha" (FOUCAULT, "La extension sociale de la norme", DE, III, 1994, p. 75).

52 Referenda-se isso através de uma passagem retirada dos Dits: "Por pensamento médico eu entendo uma maneira de perceber as coisas que se organizam entorno da norma, ou seja, que tenta repartir o que é normal e o que é anormal", assim como ao falar em pensamento jurídico ele busca repartir aquilo que se diz ser lícito do que é ilícito (FOUCAULT, "Le pouvoir, une bête magnifique", DE, III, 1994, p. 374). 


\section{A lição dos "homens infames" 53}

Em janeiro de 1977 Michel Foucault escreve, para Les cahiers $d u$ chemin, um artigo entitulado "La vie des hommes infâmes" (FOUCAULT, DE, III, 1994). Foucault se debruça em documentos emitidos em nome do rei e que "tinham por função sujeitar a medidas de segurança, tais como a prisão ou o internamento todo indivíduo cujos comportamentos eram, nos discursos desses mesmos documentos, tipificados de 'indesejáveis'" (FOUCAULT, "La vie des hommes infâmes", DE, III, 1994, p. 237). Nas palavras de Gilles Deleuze, "um dos textos mais violentos de Foucault" e, ao mesmo tempo, "o mais engraçado também" (DELEUZE, 1990, p. 134). Acredita-se que esses escritos, apesar da necessidade de se fazer os devidos deslocamentos históricos, reatualizando -os para os dias atuais (pois sua referência repousa nos anos de 1660-1760), espelham, de maneira bastante privilegiada, a forma pela qual a sociedade reparte a relação entre sujeito, verdade e poder.

Ao falar dos homens infames não se trata de buscar uma referência de vida ou de existência nas grandes personalidades, nos sujeitos consagrados seja pela história, seja localmente, em alguma fração de sociedade e lugar em que ele esteja instalado. Tal personalidade tranformar-se-ia em cânone a ser seguido, em diapasão comparativo cujos atos poderiam adquirir, talvez, ainda que momentaneamente, o estatuto de conduta exemplar, quase universal. As pessoas

53 Como suporte das traduções do francês para o português de "A vida dos homens infames" será utilizada a edição portuguesa de 1992, contida no livro $O$ que é um autor?. 
comuns seriam, na melhor das hipóteses, repetidoras desses grandes e valorosos homens.

Em "La vie des hommes infâmes" é o reverso disso o que é encontrado. Foucault faz o leitor deparar-se com os homens comuns; ou "pior", homens colhidos pela leitura de fragmentos de vidas, por "antologia de existências", aqui ou ali "sufocadas" socialmente ao adotarem práticas incomuns: Mathurin Milan era louca por sempre "esconder-se da família [e] levar uma vida obscura no campo"; Jean Touzard foi acusado de "'Frade apóstata, sedicioso" e sodomita (FOUCAULT, "La vie des hommes infâmes", DE, III, 1994, p. 237-238). Por que isso acontecia? Por que a sociedade se esmerara tanto para calar esses gritos quase inaudíveis?

Antes de responder a isso Foucault faz algumas observações: seriam tais escritos menos afeitos aos historiadores do que escritos de humor e subjetivos? Ou "livro de convenção e de jogo"? Daria no mesmo, talvez, diz ele, contanto que a captação desses personagens obedecesse a certas regras: que fossem reais, com existências "obscuras e desafortunadas", contadas em poucas páginas ou frases; que os relatos apresentados não fossem anedotas, mas tivessem "realmente feito parte da história minúscula daquelas existências, da sua infelicidade, da sua raiva ou da sua duvidosa loucura"; e que o "efeito" dessas histórias fosse a mistura de "beleza e pavor" (FOUCAULT, “La vie des hommes infâmes", DE, III, 1994, p. 239). Regras, na verdade, utilizadas por Foucault para "reencontrar algo como aquelas existências-clarão, como aqueles poemas-vida" (FOUCAULT, "La vie des hommes infâmes", DE, III, 1994, p. 239). 
Entranhamente, como esses homens infames encontraram visibilidade? Não deveriam ter ficado em um espaço nebuloso e imperceptível, sem serem "arrancados à noite", nas belas palavras de Foucault? Sim, caso não fossem postos à luz pelo "encontro com o poder" - eis a primeira grande conclusão foucaultiana (FOUCAULT, "La vie des hommes infâmes", DE, III, 1994, p. 240). Ou seja, "O poder que vigiou aquelas vidas, que as perseguiu, que, ainda que por um só instante, prestou atenção às suas queixas e ao seu leve burburinho e que as marcou com um golpe das suas garras"; ao mesmo tempo, também um poder "que suscitou as poucas palavras que delas nos restam" (FOUCAULT, “La vie des hommes infâmes", DE, III, 1994, p. 241). Ou um poder que termina sendo "O ponto mais intenso das vidas, aquele em que se encontra a sua energia, encontra-se efetivamente onde elas se confrontam com o poder, se batem com ele, tentam utilizar-lhe as forças ou escapar-lhe às armadilhas" (FOUCAULT, "La vie des hommes infâmes", DE, III, 1994, p. 241).

Trata-se aqui da observância dos detalhes da vida cotidiana, do "universo ínfimo das irregularidades e das desordens sem importância" (FOUCAULT, "La vie des hommes infâmes", DE, III, 1994, p. 245): antes, feita pela Igreja, cuja confissão fazia "passar pelo fio da linguagem o minúsculo mundo de todos os dias, os pecadilhos, as faltas, mesmo que imperceptíveis, até aos turvos jogos do pensamento, das intenções e dos desejos" (FOUCAULT, "La vie des hommes infâmes", DE, III, 1994, p. 245); a partir de finais do século XVII, papel reservado ao Estado, que irá substituir o plano religioso pelo administrativo, o perdão pelo registro. Vai haver lugar para a denúncia e o inquérito, para o relatório e o dossiê, cuja contrapartida poderá ser o enclausuramento. 
Os minúsculos gestos de cada um são, portanto, vigiados. Estes gestos vão incluir, nos documentos estudados por Michel Foucault, desde a bebedeira até a desobediência familiar, desde a má administração financeira às injúrias ou agressões no âmbito familiar. Todos esses microproblemas são resumidos por Foucault como "pequenos desvios de conduta" (FOUCAULT, "La vie des hommes infâmes", DE, III, 1994, p. 246). Mas quem fazia a denúncia? Não o rei, propriamente e na maioria das vezes, mas as pessoas da proximidade dos acusados: os familiares (pai, mãe ou filhos), os vizinhos, "o pároco por vezes, ou algum notável" (FOUCAULT, "La vie des hommes infâmes", DE, III, 1994, p. 246). Não abuso do poder absoluto do monarca, mas extensão desse poder a todos aqueles que, habilidosos, sabendo "jogar o jogo [poderem] tornar-se face ao outro um monarca terrível e sem lei: homo homini rex" (FOUCAULT, "La vie des hommes infâmes", DE, III, 1994, p. 247).

Em suma, o vigiar as pessoas é um fenômeno que não precisava se prender aos grandes monumentos do poder, ao Estado, por exemplo. É no entorno da vida diária de cada um que a pressão do enquadramento normalizador se faz mais presente. Daí a conclusão foucaultiana de que "A intervenção de um poder político sem limites nas relações quotidianas torna-se, assim, não apenas aceitável e familiar, mas também profundamente desejada" (FOUCAULT, "La vie des hommes infâmes", DE, III, 1994, p. 247), embora as coisas fossem mudar. Endereçadas diretamente ao rei, como "primeiro afloramento do quotidiano no código do político", a linguagem das denúncias era por demais "decorativa", "desproporcional", "empolada" (FOUCAULT, “La vie des hommes infâmes", DE, III, 1994, p. 249, grifo nosso). 
Para Foucault, se uma série de coisas mudará, como se disse, a atenção dada à vida cotidiana vai permanecer. $\mathrm{Na}$ virada do século XVIII instar-se-á "uma rede fina, diferenciada, contínua, onde se disseminam as diversas instituições da justiça, da política, da medicina, da psiquiatria" (FOUCAULT, "La vie des hommes infâmes", DE, III, 1994, p. 250). Agora, com uma linguagem utilizada menos imprecisa, recorrentemente saída das mãos dos homens comuns ou humildes, uma linguagem com pretenções objetivas fortalece o discurso de denúncia:

[...] o discurso que se irá formar então já não terá uma teatralidade artificial e inepta; desenvolver-se-á numa linguagem que terá a presunção da observação e da neutralidade. $\mathrm{O}$ banal será analisado de acordo com a grelha eficaz, mas cinzenta da administração, do jornalismo e da ciência (FOUCAULT, "La vie des hommes infâmes", DE, III, 1994, p. 250)

Por que a relação quotidiano-poder permanecerá? Já se viu: o poder político e suas instituições variadas não se valerão apenas de proibições e recusas, vigias e punições. $\mathrm{O}$ enquadramento que se quer obedecerá à estratégia de usar o poder também para "incitar", "sucitar", "agir" e "falar" (FOUCAULT, "La vie des hommes infâmes", DE, III, 1994, p. 251). Nessa obsessão de dizer a verdade própria do Ocidente que, como tal, é uma forma de "coação" - conclui Michel Foucault - a literatura aparece de forma ambígua: embora fazendo parte desse sistema de coação, "ela terá a tendência de pôr-se fora da lei, ou pelo menos tomar a seu cargo o 
escândalo, a transgressão ou a revolta” (FOUCAULT, "La vie des hommes infâmes", DE, III, 1994, p. 252). Deleuze, em sua pequena monografia sobre Foucault (1988), disse que o que estava em questão era o seguinte:

Se o poder é constitutivo de verdade, como conceber um "poder de verdade" que não seja mais verdade de poder, uma verdade decorrente das linhas transversais de poder? Como "ultrapassar a linha"? [...] O que resta, então, salvo essas vidas anônimas que só se manifestam em choque com o poder, debatendo-se com ele, trocando com ele 'palavras breves e estridentes', antes de voltar para a noite, o que Foucault chamava 'a vida dos homens infames' (DELEUZE, 1988, p. 102)?

Cabe lugar agora retomar aquela questão colocada por Habermas relativamente a sua crítica de uma aporia do poder presente na obra foucaultiana, pois a conclusão do texto sobre os homens infames deixa à vista a relação entre o quotidiano das pessoas e o poder. Haveria alguma saída para isso, e que servisse também de resposta para Habermas? Sem quere levar o mérito mesmo da questão longe demais, indica-se aqui uma possível resposta de Foucault: de fato, o poder - que antes de tudo é uma "relação" - "está sempre presente", em "diferentes níveis" e sob "diferentes formas". Mas se ele está em toda parte, se isso toca diretamente na questão das liberdades pessoais, a posição de Foucault caminhou no sentido totalmente contrário à de Habermas: "se há relações de poder através de todo corpo social, é porque há liberdade por toda parte", e o grande erro foi não ver que "as relações de poder não são 
alguma coisa de mal em si" (FOUCAULT, "L'éthique du souci de soi comme pratique de la liberté", DE, IV, 1994, p. 720, 727).

Ora, de um lado a lição dos "homens infames", a lição tirada desse texto é de que há poderes localizados que muitas vezes tentam barrar comportamentos "diferentes". Ser diferente, entrar em situações ou comportamentos que fogem dos padrões sociais não raramente desperta as forças reacionárias da sociedade, ao ponto de que a liberdade de contra-poder será sempre uma possibilidade à espreita (esse tema precisará ser retomado no Capítulo seguinte, endereçado ao traço personalístico do esteta).

Por outro lado, valorizando a lição dos homens infames, o caso seria talvez identificar as formas sociais de dominação, na verdade "jogar com o mínimo possível de dominação" e descobrir os focos de "resistência" [résistance] (FOUCAULT, "L'éthique du souci de soi comme pratique de la liberté", DE, IV, 1994, p. 727). Entra-se aí na distinção feita por Foucault entre "jogos estratégicos entre liberdades" e os "estados de dominação" (o que se chama ordinariamente de poder) (FOUCAULT, "L'éthique du souci de soi comme pratique de la liberté", DE, IV, 1994, p. 728). Em todo caso, resistir é de início "dizer não" e "fazer desse não uma forma de resistência decisiva" (FOUCAULT, "Michel Foucault, une interview: sexe, pouvoir et la politique de l'identité", DE, IV, 1994, p. 741). Daí um novo par a ser observado: o par poder-resistência. Há sempre poder e há sempre resistência. Resta saber se o caminho a ser seguido poderá aportar, de maneira mais definitiva, no âmbito do personagem conceitual de "crítico". Resta saber acerca do que terá a dizer as suas três dimensões da crítica, como a seguir. 


\section{As "dimensões" arqueológica, genealógica e estratégica da crítica}

Em "Qu'est-ce que la critique? [Crítique y Aufklärung]" (FOUCAULT, 1995), Michel Foucault a certo instante começa a propor de foma mais contundente o seu entendimento específico acerca da atitude crítica. Ele nomeia algumas diretrizes: primeiro, sem querer descampar para uma filosofia da história ou para uma história da filosofia, trata-se de empreender uma prática "histórico-filosófica". Esta deve ir além da busca por uma "experiência interna" do sujeito - as críticas à corrente fenomenológica são expostas com vigor -, bem como buscar conteúdos históricos "preparados por historiadores e retomados, de maneira elaborada, como fatos" (FOUCAULT, 1995, p. 10).

A prática histórico-filosófica deve elaborar ao seu modo a sua "ficção", e sempre buscar aí respostas à "pergunta sobre as relações entre as estruturas de racionalidade que articulam o discurso verdadeiro e os mecanismos de sujeição ligados a esses discursos", indagações que excedem o âmbito do historiador (FOUCAULT, 1995, p. 10-11). Como trabalhado no Capítulo I, a história e a filosofia não podem conviver separadamente, e a esse imperioso conluio Foucault o resume da seguinte maneira: "[...] dessubjetivar a questão filosófica recorrendo ao conteúdo histórico e liberar os conteúdos históricos graças à interrogação sobre os efeitos de poder que os afeta em virtude da verdade que dizem revelar" (FOUCAULT, 1995, p. 11).

Em segundo lugar, se foi com Kant e a questão da Aufklärung que uma tradição crítica foi instaurada, é imprescindível entender esse momento como uma época privilegiada. 
Dizendo isso Foucault não pretende negar que o século XVIII, por exempo, encontrou suas raízes no XII, comparações possíveis com outras tantas épocas, mas "tentar ver sob que condições, ao preço de quais modificações ou de quais generalizações, pode-se aplicar a qualquer momento da história essa pergunta da Aufklärung" (FOUCAULT, , 1995, p. 12).

$\mathrm{O}$ "resgate" de Michel Foucault da atitude crítica inaugurada por Kant aparece na conferência "Qu'est-ce que la critique? [Crítique y Aufklärung]" como uma porposição algo "vaga". Falando modestamente ao público (entende-se isso como a presença do traço personalístico do "professor-pesquisador", conforme a ideia vista pela lente de Noguera-Ramírez, 2011), propõe ele "sugestões" diversas para o problema, opondo uma busca pela "legitimidade do conhecimento", por uma "eventualização", ${ }^{54}$ cujos aspectos deveriam conter "O caráter arqueológico da investigação histórico-filosófica"; o caráter "genealógico" e o "estratégico" de tal investigação, entendendo-os como "três dimensões necessariamente simultâneas da mesma análise", requisito para se completar o procedimento crítico.

Sobre o aspecto da arqueologia, já se falou desde o primeiro Capítulo desta tese. Cabe sinalizar aqui apenas que, nesta conferência proferida em maio de 1978 (“Qu'est-ce que la critique? [Crítique y Aufklärung]"), Michel Foucault ainda revive o seu antigo projeto metodológico dos anos de 1960. Ao público o que ele faz é, notadamente, realçar alguns aspectos. Foucault reforça a sua não busca por coisas como "certo

54 Na nota de rodapé n. 5 dessa conferência (1995, p. 13), o próprio Foucault se desculpa pelo termo algo estranho, embora já o tivesse utilizado em L'archéologie du savoir (2005). 
ou falso, fundamentado ou não, real ou ilusório, científico ou ideológico, legítimo ou abusivo", pois sua pretensão será buscar com a pesquisa arqueológica "os laços, as conexões, que podem ser descobertas entre mecanismos de coerção e elementos de conhecimento" (FOUCAULT, 1995, p. 13).

Em outras palavras, buscar as conexões entre conhecimento e poder, os seus "jogos de envio mútuo e de apoio", os efeitos de um sobre o outro, a racionalidade que se defende relativamente ao primeiro aspecto, o gnosiológico, mostrando aos seus proponentes a cada momento suas justificações, seus cálculos e eficácia técnica. A aceitabilidade de um conjunto de conhecimentos prende-se a um contexto histórico-cultural, e se o discurso está atado ao poder, se não é possível separar um do outro, é porque a cada regra discursiva legitimada vai portar seus "efeitos de restrição" (FOUCAULT, 1995, p. 14).

Ideia que não deixou Foucault salvaguardado de inúmeras críticas. Pode-se citar alguns autores clássicos bem recorrentes, como Baudrillard (1984), Merquior (1988) ou Habermas (1990), cujas teses vão inclusive apontar para um Foucault algo retórico, niilista e cético, mas todos eles apontando o problema geral da relação saber-poder. Do primeiro deles retirase tal passagem:

A escrita de Foucault é perfeita, já que o próprio movimento do texto traduz admiravelmente aquilo a que se propõe: esta espiral generativa do poder, que não é mais uma arquitetura despótica, mas um encadeamento em abismo [...] Enfim, o discurso de Foucault é um espelho dos poderes que ele descreve (BAUDRILLARD, 1984, p. 11, 13). 
Em outras palavras, se Foucault via o poder em tudo, isso já partia do seu próprio estilo, e talvez até só servisse para reafirmar esse estilo mesmo. Fora de ambições estéticas, fora do empenho inegável de uma bela escrita, os escritos de Foucault não conduziam a nada. Pior ainda, por ser um estilo-poder incitante, sedutor, só por conta de tais artimanhas conseguia, aos menos avisados, convencer, mostrar razões legítimas relativas a conhecimentos. E levar os menos atentos, poder-se-ia assim interpretar Baudrillard, mais para abismos disfarçados pela retórica da linguagem, suas artimanhas e engenhosidades, do que para clareiras. ${ }^{55}$

Quanto a Habermas a sua crítica em torno da questão do saber/ poder é mais evidente ainda, e ele dá a isso a expressão "aporias de uma teoria do poder":

O conceito de poder em Foucault não permite um tal conceito de contra-poder que se apoiaria sobre uma filosofia da história e conferiria privilégios cognitivos. Cada contra-poder move-se já no horizonte do poder que ele combate e transformase, logo que vitorioso, num complexo de poder que provoca outro contra-poder. A genealogia do saber não pode sair deste

55 Há certa plausibilidade nas críticas de Baudrillard. Na defesa de sua tese de doutorado "Folie et Déraison", "M. Canguilhem fala de retórica quanto a certos fragmentos e o presidente acha-o demasiado zeloso na busca do 'efeito' “" (ERIBON, 1990, p. 144). Em 1972, quando da reedição desse livro, Foucault mesmo dirá a Claude Maurice (apud ERIBON, 1990, p. 153): "Se eu tivesse de voltar a escrever este livro hoje integrarlhe-ia menos retórica". Por fim, J. Merquior lembraria ao leitor de incluir Foucault na tradição de glamour da escrita, antes do que rigor filosófico, seguindo os passos de Bergson e Sartre (MERQUIOR, 1988, p. 14). 
círculo enquanto ativar a insurreição das formas desqualificadas do saber e mobilizar o saber oprimido contra o constrangimento de um discurso teórico, formal e científico (HABERMAS, 1990, p. 263-4).

Habermas tinha razão, parcialmente pelo menos. Não há uma luta contra um poder estabelecido que, se vitorioso, não se instalasse ainda nesse reino de poder. Porém, até que ponto este seria um "círculo vicioso" para Foucault? Até que ponto um poder de horizontes tão amplos, chamados de microfísico por Michel Fopucault - que, como os átomos, estão por toda parte - excluiria iniciativas legítimas em prol de processos libertários? A lição dos "homens infames" parece propor uma resposta a isso, mas cabe ainda citar a posição defendida por John Rajchman:

O modelo de crítica concebido por Foucault é distinto do neokantiano de Habermas. Sua crítica não é uma tentativa do uso de normas racionais numa análise geral do Estado ou da sociedade; consiste mais numa constante 'desobediência civil' dentro de nossa experiência constituída (RAJCHMAN, 1987, p. 11)

Quanto a Merquior, ele fala de uma ideologia contracultural que perpassaria a obra de Foucault, "profundamente equivocada", pois "rebelião contra a ilustração como fonte principal e paradigma da moderna cultura nacional-liberal". Como, insiste ele, "desmistificar a cultura" sem conservar um "modelo de verdade capaz de distinguir a teoria da ideologia, 
o conhecimento da mistificação"? (MERQUIOR, 1988, p. 275) A conclusão de Merquior é grave: Foucault é um autor híbrido, meio nostálgico, como Nietzsche, e por outro lado cético, como um bom pensador "moderno" (MERQUIOR, 1988, p. 271, 275, 271), inviabilizando de resto o ideário científico. Ou seja, como alguma história pode ser realmente coerente se não reserva certos espaços para uma "descrição da ciência, sua natureza e seus efeitos"? Foucault, ao voltar-se para os conhecimentos informais ao invés de levar seriamente em conta a ciência, tornou tal procedimento, pensa Merquior, "fatal para seu programa" (MERQUIOR, 1988, p. 280).

As críticas de Habermas e de Merquior são, particularmente aí, rebatidas por Sergio Rouanet. Para este, numa passagem longa, mas bastante enfática, se se vê uma denúncia sistemática de Foucault pela ciência, cabe notar que ele não pretendia, ao contrário, destruí-la, condenar a razão científica, enfim, senão apontar para relações de poder presentes no seu interior. Ou seja,

[...] mostrar os condicionamentos précientíficos da ciência (configurações de poder) e sua refuncionalização para fins extracientíficos, o que está na melhor tradição (moderna) da filosofia não-positivista, inclusive do próprio Habermas, e propor, como alternativa para as ciências humanas e para a historiografia tradicional, uma arqueogenealogia que atenda a requisitos de cientificidade pelo menos tão exigentes quanto os aplicados às ciências tradicionais. Não se trata de rejeitar o saber, mas de combater os efeitos de poder inerentes ao funcionamento da 
ciência, invocando, nesse combate, não a desrazão, a intuição, o elan vital ou a vontade de poder, mas, prcisamente, o saber, ou saberes, localizados nos bas-fonds da ciência oficial (ROUANET, 1987, p. 220).

O caráter arqueológico da investigação histórico-filosófica, aportando nas malhas discursivas, sem idealizações de qualquer espécie precisaria, assim, passar para um outro nível, ser completado pela pesquisa genealógica, que encontra maior dentendimento caso não se fique preso àquilo que, sinteticamente, está dito em "Qu'est-ce que la critique? [Crítique y Aufklärung]" acerca da noção foucaultiana de genealogia. $\mathrm{O}$ tema da genealogia em Foucault, caso se tome a sua démarche de forma repartida, surge nos anos de 1970 como uma pesquisa voltada para a genealogia do poder, (com Surveiller et punir e La volonté de savoir); e como uma genealogia da ética, quando, em 1984, aparecem L'usage des plaisirs e Le souci de soi.

A genealogia do poder põe uma questão fundamental: como o saber se engaja em estruturas sociais e em efeitos de poder (formas sociais e políticas)? Tal questionamento direcionou os estudos foucaultianos em Histoire de la folie e em Naissance de la clinique. O poder nesse contexto, porém, vai reconhecer Foucault a partir da década de setenta (e expressamente em 1971), foi "mal isolado" e compreendido. Ou ele era colocado em termos jurídicos (soberania, constituição etc.) ou segundo o viés da esquerda marxista (os aparelhos de Estado). Como o poder era concretamente exercido, quais suas táticas e técnicas, isso ficava sem uma resposta devida (FOUCAULT, "Entretien avec Michel Foucault", DE, III, 1994, p. 144), embora, sobretudo em Histoire de la folie, abordar o 
problema em termos de repressão, daquilo que apenas "diz não", bastou para dar conta do objeto investigado. ${ }^{56}$

Há algumas interpretações dessa virada foucaultiana que cabe ser citada. Na síntese de Gros (1997, p. 84), a partir de Surveiller et punir Foucault, que não busca mais, como naquela obra, uma experiência fundamental como elemento de sistematização dos gestos e dos discursos, pensará em uma tática geral de poder como centro de produção de diversos saberes e práticas. Em outras palavras, Foucault tenta inverter a perspectiva de Durkheim, para quem a sociedade tradicional era pensada em termos de coesão social. Mas se, com Histoire de la folie, põe-se acento no sistema de exclusão do louco, a complexidade do sistema carcerário exigirá que se vá além de tais funções puramente negativas ficando, assim, a pergunta: qual papel terá a "prisão para o exercício e manutenção do poder?" (FOUCAULT, "À propôs de la prison d'Attica", DE, I, 2001, p. 1396). Investigando isso, o trabalho de Foucault, como colocado na importante conferência "La vérité et les formes juridiques", não estará ligado à arte, mas a uma atividade histórico-política libertadora, se se pensa em uma arqueologia como "máquina crítica" (FOUCAULT, DE, I, 2001, p. 1512).

Para Roberto Machado a virada genealógica está na mudança do "como" os saberes aparecem e se transformam, que Histoire de la folie, Naissance de la clinique e Les mots et les choses elaboraram, para a resposta ao "por quê"; ou seja, "explicar o aparecimento de saberes a partir de condições de

56 André Queiroz (1999, p. 22) lembra que o problema da "passagem" da Histoire de la folie à Surveiller et punir estava em uma concepção essencialista da loucura ou experiência originária, encontrada nesta primeira obra, e que desaparece em seguida. 
possibilidade externas aos próprios saberes, que imanentes a eles [...] os situam como elementos de um dispositivo de natureza essencialmente estratégica". Em outras palavras, o poder poderá "explicar a produção dos saberes" (MACHADO, in: FOUCAULT, 1979, p. X). Para Rabinow e Dreyfus, a genealogia surge justamente de um projeto arqueológico de Foucault, que "fracassa", e por dois motivos: 1) "o poder causal atribuído às regras que governam os sistemas discursivos é ininteligível e torna incompreensível o tipo de influência que as instituições sociais têm"; e 2) se a arqueologia é um "fim em si mesmo", ela "exclui a possibilidade de apresentar suas análises críticas em relação às preocupações sociais "(RABINOW; DREYFUS, 1995, p. XXI). Foucault, então, faz um "desvio", afastando-se de uma "teoria do discurso" e mais ainda do estruturalismo, tomando a genealogia nietzscheana como "ponto de partida" para o seu novo método.

Não se deve, dessa forma, desconsiderar o importante escrito "Nietzsche, la genealogia, l'histoire". ${ }^{57}$ Neste, Foucault realça que a genealogia se opõe a uma "pesquisa da 'origem'", quando esta quer apontar para uma meta-história "das significações ideais e das indefinidas teologias" (FOUCAULT, DE, I, 2001, p. 1005). A pesquisa pela "origem" em Nietzsche, segundo Foucault, não descobrirá essências veladas, mas, ao contrário, a não-essência que subsiste no recuo; não uma certa identidade preservada, mas a "discórdia" e o "disparate". Por exemplo, de uma razão nascida do 'desrazoável', de uma "dedicação à verdade" dos cientistas, vindas de sua paixão

57 GIACÓIA JÚNIOR (In: MARIGUELA, (Org.), 1995, p. 82) indica que os principais textos de Nietzsche utilizados por Foucault sobre a genealogia "serão Para além de bem e mal e Para a genealogia da moral". 
e ódios recíprocos, seja em suas fanáticas e recorrentes discussões, seja por querer "suprimir a paixão" mesma. Enfim, a liberdade não seria, até ela, uma 'invenção das classes dominantes' (FOUCAULT, "Nietzsche, la genealogia, l'histoire", DE, I, 2001, p. 1006)?

Segundo, se na origem somos tentados a buscar o altivo e divino, a genealogia mostra o contrário disso: no princípio, no "limiar" está o macaco do Zaratustra nietzscheano. ${ }^{58}$ Como escreve Foucault, o começo é "derrisório" e "irônico" (FOUCAULT, "Nietzsche, la genealogia, l'histoire", DE, I, 2001, p. 1007). Quando Nietzsche, segundo Giacóia, buscou entender a disposição do bem e do mal na nossa sociedade foi as entendendo "não como se elas encontrassem seu fundamento numa origem metafísica ou transcendente, mas como integrando o domínio imanente e contingente da natureza" (GIACOÍA JÚNIOR, In: MARIGUELA (Org.), 1995, p. 83). A "falta de sentido histórico'" consistiu no grande "pecado original da filosofia crítica ou dogmática" (GIACOÍA JÚNIOR, In: MARIGUELA (Org.), 1995, p. 83).

Em terceiro lugar, a origem não é o lugar do verdadeiro. $\mathrm{Na}$ origem o que se encontra é o acaso. Assim, a partir de uma análise da obra nietzscheana, Foucault busca mostrar como Entestehung ou Herkunft dizem melhor a "origem" do que

58 Sobre isto escreve Gilles Deleuze: “Bobo (Macaco, Anão ou Demônio) - É a caricatura de Zaratustra. Imita-o, mas como a lentidão imita a ligeireza. Ele também representa o maior perigo de Zaratustra: a traição da doutrina. O bobo despreza, mas o seu desprezo vem do ressentimento. Ele é o espírito da lentidão. Como Zaratustra, pretende ultrapassar, superar. Mas superar significa para ele: ou fazer-se carregar (subir para os ombros do homem, e do próprio Zaratustra); ou, então, saltar por cima. São os dois contra-sensos possíveis sobre o 'super-Homem'”' (DELEUZE, 1994, p. 36). 
"Ursprung". "Herkunft", que indica proveniência, não pode apontar, no genealogista, para uma marca inicial a partir da qual, por evolução, chegou-se ao que há hoje, à nova espécie. A pesquisa acerca da proveniência deve indicar a "dispersão" que a marcou, "os acidentes, os ínfimos desvios [...]; é descobrir que na raiz daquilo que nós conhecemos e daquilo que nós somos - não existem a verdade e o ser, mas a exterioridade do acidente" (FOUCAULT, "Nietzsche, la genealogia, l'histoire", DE, I, 2001, p. 1009). Se a pesquisa pela proveniência não atinge um fundamento, abre, na realidade - pois descobre o não-imóvel, o fragmentado, o heterogêneo - o espaço para a crítica.

"Entestehung" significa emergência ou surgimento, a lei que faz algo aparecer. Para Nietzsche, segundo Foucault, ela diz na verdade a "entrada em cena das forças". Sua análise genealógica [de Nietzsche] da noção de bom não seria nem a "energia dos fortes nem a reação dos fracos", mas a "distribuição" dessas forças antagônicas nesse "não-lugar", nesse "interstício" onde elas são produzidas. Cenas de teatro. Aidéia de liberdade nasce dessa peça onde "classes dominam classes" (FOUCAULT, "Nietzsche, la genealogia, l'histoire", DE, I, 2001, p. 1012). Eu seria livre no momento em que pudesse conviver em paz e numa relação com os meus semelhantes de direitos e deveres recíprocos? Não:

O desejo da paz, a doçura do compromisso, a aceitação tácita da lei, longe de serem a grande conversão moral, ou o útil calculado que deram nascimento à regra, são apenas seu resultado e propriamente falando sua perversão. 'Falta, consciência, dever têm sua emergência no direito de 
obrigação; e em seus começos, como tudo o que é grande sobre a terra, foi banhado de sangue'(FOUCAULT, "Nietzsche, la genealogia, l'histoire", DE, I, 2001, p. 1013)

Dominar e fazer regras que favoreçam essa dominação - tal é a direção básica do caminhar da humanidade, não sua lenta evolução. Por fim, tanto a história é a manifestação desse "acaso da luta", quanto o historiador é, na verdade, alguém que nunca se vale de uma pesquisa objetiva. Seu olhar para o passado sempre se dá a partir da sua "perspectiva" (FOUCAULT, "Nietzsche, la genealogia, l'histoire", DE, I, 2001, p. 1016-1018) e o "querer" nele é indissociável do "saber"; além disso, se crê em causas finais, é porque se assenta em uma visão teológica (FOUCAULT, "Nietzsche, la genealogia, l’histoire", DE, I, 2001, p. 1019).

São essas algumas das características principais da genealogia nietzscheana, identificadas por Foucault em "Nietzsche, la genealogia, l'histoire", e incorporadas à sua investigação pessoal, genealogia que pode ser caracterizada ainda mais em se tomando novamente de empréstimo os Dits etécrits (e um pouco de Habermas), a saber: 1) que ela é uma forma de história que investiga a constituição dos saberes, discursos, domínios dos objetos etc. sem se referir a um sujeito (FOUCAULT, "Entretien avec Michel Foucault", DE, III, 1994, p. 147); 2) as genealogias são anticiências, no sentido de que se trata de investigar "os saberes locais, descontínuos, desqualificados, não legítimos, contra a instância teórica unitária que pretenderia filtrá-los, hierarquizá-los, ordená-los em nome de uma ciência verdadeira", uma ciência que seria apenas "detida por alguns" (FOUCAULT, “Cours du 7 janvier 1976", DE, III, 1994, p. 165). 
O saber instituído é na verdade "saber sujeitado" [savoir assujetti], historicamente "sepultados" ou "disfarçados" através de "coerências funcionais" ou "sistematizações formais". Segundo, escreve ainda Foucault em um dos seus cursos no Collège de France, (FOUCAULT, "Cours du 7 janvier 1976", DE, III, 1994, p. 164), é também um saber que desqualifica outros saberes, inferiorizando-os por os considerar não-científicos, não-conceituais etc., cabendo à pesquisa genealógica voltar a qualificá-los. Daí a arqueologia ser o método de análise das "discursividades locais", enquanto a genealogia ser a "tática" para a eclosão daqueles saberes "des-sujeitados" (FOUCAULT, “Cours du 7 janvier 1976”, DE, III, 1984, p. 167). Nesse sentido, "as genealogias são muito exatamente anticiências” (FOUCAULT, “Cours du 7 janvier 1976”, DE, II 1994, p. 164). Assim, "é bem contra os efeitos de poder próprios a um discurso considerado como científico que a genealogia deve conduzir o combate" (FOUCAULT, "Cours du 7 janvier 1976", DE, III 1994, p. 166).

Mas há outras características da genealogia, na sequência do que foi dito: 3) a busca genealógica parte de uma questão presente, atual (até porque o recuo no passado não envia o pesquisador para alguma instância de fundamento); 4) o nível discursivo, marcado pelas epistémês, dá lugar a noções como "dispositivo", que engloba também o extra-discursivo, como instituições, leis, medidas administrativas etc., articulados em torno do par produção de saber-exercício de poder;"59 5)

59 Há lugar aqui para citar uma crítca desferida por Habermas: o genealogista partirá da "hipótese segundo a qual a única coisa que perdura é o poder que volta sempre a aparecer sob máscaras novas na mudança dos processos de subjugação" (HABERMAS, 1990, p. 239), crítica a qual Foucault estava ciente, e que chegou a respondê-la brevemente: de fato, 
por fim, nessa caracterização geral ora dada, que nela há três domínios, nunca deixados de lado por Foucault, até presentes na fase arqueológica anterior: uma genealogia histórica de nós mesmos na relação com a verdade (seus estudos da década de sessenta), depois uma genealogia de nós em nossas relações a um campo de poder, e ainda uma genealogia de nossas relações com a moral, permitindo às pessoas se constituírem, respectivamente, como sujeitos de conhecimento, sujeitos de ação sobre os outros e agentes éticos.

Pontuado esses aspectos ligados à noção de genealogia em Foucault (mas sem atravessar ainda o sítio da genealogia da ética), pode-se prosseguir naquilo que foi realçado por ele em "Qu'est-ce que la critique? [Crítique y Aufklärung]". Resumindo tudo o que foi dito sobre o referido assunto, Foucault fala acerca de alguns "perigos" como "conseqüências negativas" do seu método. Primeiro, que se deve "desprender as condições de aceitabilidade de um sistema e seguir as linhas de ruptura que marcam a sua emergência" (FOUCAULT, 1995, p. 15).

Em segundo lugar, compreender que "a análise dessas positividades puras são, de algum modo, singularidades puras; nem encarnação de uma essência, nem individuação de uma espécie". Nesse sentido, manter-se nesse campo de

o poder - que antes de tudo é uma "relação" - "está sempre presente", em "diferentes níveis" e sob "diferentes formas". Mas se ele está em toda parte, então não há liberdade? A resposta vai ao contrário: "se há relações de poder através de todo corpo social, é porque há liberdade por toda parte", e o grande erro foi não ver que "o poder não é o mal" em si mesmo, apenas uma realidade interposta em um conjunto de jogos estratégicos (FOUCAULT, "L'éthique du souci de soi comme pratique de la liberté", DE, IV, 1994, p. 720, 727). 
singularidade pura significaria - e aí dá-se a entrada de um conceito fundamental - nem fazer uma filosofia da história e nem um trabalho de historiador, quer dizer, nem buscar algum tipo de teleologia do percurso filosófico (Hegel é o exemplo mais claro disso), nem ver a história pela lente de processos causais. As singularidades puras apontam para o campo de "imanência" dos acontecimentos (FOUCAULT, 1995, p. 15).

Em resumo, após esses dois traços relatados por Foucault na sua conferência, mas que tinham por substrato tudo o que foi trabalhado anteriormente, ele conclui que a genealogia busca "restituir as condições de aparição de uma singularidade a partir de múltiplos elementos determinantes, em relação com os quais essa singularidade aparece não como o produto, senão como o efeito" (FOUCAULT, 1995, p. 16). O passo seguinte é entender que o caráter estratégico dessa pesquisa há de ser observado. Primeiro, não vendo aí, nas singularidades onde se alojam os sujeitos ou grupos e suas interações, momentos fixos. As interações e suas redes proporcionam "margens sempre variáveis de não certeza"; em segundo lugar, são características intrínsecas dessas relações estarem mesmo em "perpétuo desprendimiento umas com respeito a outras" (FOUCAULT, 1995, p. 17). 